\title{
ECONOMIC VALUATION OF FEMALE \\ FAMILY LABOUR IN AGRICULTURE AND \\ ANIMAL HUSBANDRY: A STUDY IN A \\ PROSPEROUS AGRICULTURAL REGION
}

Kavita Baliyan*

\begin{abstract}
The present paper seeks to examine the economic contribution of women of cultivating households in agriculture and allied activities in an agriculturally prosperous region. The paper quantifies the labour time spent by household women in activities related to farming and animal husbandry. It also seeks to measure the economic contribution of women in the household income in monetary terms. The study is based on primary data collected through a survey of 240 farm households belonging to Muzaffarnagar and Baghpat districts located in agriculturally developed western Uttar Pradesh (UP). The study reveals that household women contribute about 20 per cent of agricultural income and 61 per cent of animal husbandry income in farm households. The contribution of female workers in family income was significant in all the farm size categories, though the share of women in family income was found to be negatively correlated with farm size. The study clearly shows that women household members contribute a significant amount of family labour and income in the farm households. It is, therefore, important that these women are treated as workers and their contribution is duly accounted for in national income statistics. Government agencies working in the field of agricultural development should focus on women workers as a special category. They should be provided proper training in agriculture and animal husbandry to improve their efficiency and knowledge. Steps need to be taken to ensure access of rural women to agricultural and livestock extension services and other support mechanisms.
\end{abstract}

*Assistant Professor, Giri Institute of Development Studies, Lucknow - 226024.

The paper is based on author's Ph.D thesis. The author is thankful to her supervisor Professor A.K. Singh for his valuable guidance and suggestions in preparation of this paper.

Journal of Rural Development, Vol. 36, No. 2, April - June: 2017 


\section{Introduction}

Household women in cultivator families spend a substantial part of their time in various activities directly related to agriculture and management of livestock. Most tedious and backbreaking tasksin agriculture and homes are done by women (Kaur, 2008). They contribute significantly to household income across all farm sizes and their earnings are found crucial for landless and small farm households (Sethi, 1991). However, their productive activities go unrecorded or are subsumed within 'domestic work' (Goswami, 2013). A large number of female workers are not enumerated as workers at the time of census, either because they do not fit into the rigid criteria for classification of a worker or because of the prevalent social and cultural bias against female participation in labour force. As Bina Agarwal has argued, the accuracy of national level statistics, which usually serve as the principal data input in the framing of development policies, is severely impaired by biases which lead to an undercounting of women, both as workers and as those available for work (Agarwal, 1985). Consequently, the crucial role of women in agriculture, allied and household activities remains underestimated and unvalued (Sethi, 1982 \& 1991; Sardamoni, 1987; Varma,
1992; Maithli, 1994; Unni, 1999; Tuteja, 2000; Pandey, 2001; Wasnik, 2006).

The present paper seeks to examine the role and economic contribution of women of cultivating households in agriculture and allied activities with particular reference to the western region of UP. The study quantifies the labour time spent by household women in activities related to farming and animal husbandry. It also seeks to measure the economic contribution of women in the household income in monetary terms.

\section{Methodology}

The study is based upon a field survey of 240 farm households belonging to Muzaffarnagar and Baghpat districts located in the agriculturally developed western region of Uttar Pradesh. For the purpose of the study two blocks were selected from each district reflecting the cropping pattern in the district. Then, two villages were randomly selected from the four selected blocks. In the final stage we selected 30 cultivating households randomly for field survey from each village representing different size classes of land holdings. The primary survey was conducted by the researcher herself during 2008-09 and the data relates to the agricultural year 2007-08.

Table 1: Distribution of Households by Size of Landholding and Average Size of Holding

\begin{tabular}{lcc}
\hline Landholding Category & Number of Households & Average Size of Holding (Ha) \\
\hline Marginal (0.0-1 ha) & $69(28.75)$ & 0.63 \\
Small (1.0-2.0 ha) & $87(36.25)$ & 1.44 \\
Medium (2.0-4.0 ha) & $50(20.83)$ & 2.53 \\
Large (above 4.0 ha) & $34(14.17)$ & 5.53 \\
All households & $240(100.0)$ & 2.27 \\
\hline
\end{tabular}

Journal of Rural Development, Vol. 36, No. 2, April - June : 2017 


\section{Study Area}

Muzaffarnagar and Baghpat are among the richest districts of U.P., well-known for their agricultural development. Overthree-fourths of the area in the two districts is undercultivation. Sugarcane and wheat are the main crops cultivated in the districts. Cropping intensity is 150 and 161 in Muzaffarnagar and Baghpat, respectively. Average size of holding is around one hectare in both the districts. The region is known for its mixed farming pattern with animal husbandry as an important subsidiary activity. Most of the cultivators belong to the J at community, well-known as a farming community.

\section{FINDINGS OF THE STUDY}

\section{Work Participation Rates}

Table 2 shows the number of workers by activity per household and work participation rate by size of holdings. Participation ratio iscalculated with reference to family members above 15 years. Work participation rate for all sample households in agriculture related activities comes to about 20 per cent for females and 49.00 per cent for males (Table 2). FWPR in agriculture is highest for marginal farmers (23.17per cent) and lowest for large farmers (15.84 per cent). A higher proportion of female members of the households are engaged in animal husbandry as compared to male members. WPR for animal husbandry comes to 61.3 per cent and 38.7 per cent for females and males, respectively.

Table 2: Number of Workers per Household and Work Participation Rates in Agriculture and Animal Husbandry on Sample Farms (Percentage)

\begin{tabular}{lcccc}
\hline Category of Farmers & \multicolumn{2}{c}{ Persons Engaged in Agriculture } & \multicolumn{2}{c}{ Persons Engaged in Animal Husbandry } \\
& Female & Male & Female & Male \\
\hline Marginal & $0.17(23.17)$ & $0.41(44.67)$ & $0.49(65.00)$ & $0.32(35.00)$ \\
Small & $0.20(19.27)$ & $0.74(49.19)$ & $0.68(64.60)$ & $0.53(35.40)$ \\
Medium & $0.18(19.64)$ & $0.56(53.73)$ & $0.62(64.80)$ & $0.38(35.20)$ \\
Large & $0.20(15.84)$ & $0.79(48.95)$ & $0.71(58.20)$ & $0.68(41.80)$ \\
Total & $0.19(19.75)$ & $0.61(48.83)$ & $0.60(61.30)$ & $0.48(38.70)$
\end{tabular}

Note: *Persons reporting as workers involved in agriculture, animal husbandry and other government and private jobs.

Figures in brackets show work participation rates.

Total Persondays of Work in Different Activities

Detailed information was collected from household members on the timespent on various economic and domestic activities. Total hours spent on work have been converted into persondays by assuming that one personday consists of eight hours of work. A household woman spends on average 202 persondays per year in agriculture and animal husbandry, while on an average a man spends 293 persondays per year on these activities (Table 3). A woman spends 54.8 persondays in agricultural activities and 148 persondays in animal husbandry. The corresponding figures for a man are 226.9 and 
66.3 persondays. Thus, women contribute about 70 per cent of family labour in animal husbandry and about 20 per cent of family labour in agriculture.

Table 3: Average Persondays of Family Labour in Agriculture and Animal Husbandry

\begin{tabular}{lcccccc}
\hline \multicolumn{7}{c}{ (Per Person Per Year / Per Household) } \\
\hline Category/Activities & Agricultural Activities & \multicolumn{2}{c}{ Animal Husbandry } & \multicolumn{2}{c}{ All Activities } \\
\hline & Female & Male & Female & Male & Female & Male \\
Marginal farmers & 57.8 & 121.7 & 181.8 & 75.2 & 239.6 & 196.9 \\
Small farmers & 55.8 & 191.9 & 156.2 & 63.7 & 212.0 & 255.6 \\
Medium farmers & 62.9 & 256.4 & 145.2 & 69.5 & 208.1 & 325.9 \\
Large farmers & 42.7 & 337.4 & 108.6 & 56.7 & 151.3 & 394.1 \\
\hline Total & 54.8 & 226.9 & 148.0 & 66.3 & 202.8 & 293.2
\end{tabular}

Looking at the pattern of family labour by size of landholdings we find that persondays spent by women in productive activities per household decline with the size of holdings particularly in case of animal husbandry (Table 3). But in case of men, we find that the persondays spent on agriculture increase sharply with increase in size of holding. This is mainly on account of more persondays required on large farms. But in case of animal husbandry,persondays are inversely related to farm size for males also. On the other hand, if we see the persondays per hectare, we find that there is inverse relationship between time spent by family labour on agricultural work and size of landholdings (Table $3 A)$.

Table 3A: Average Persondays of Family Labour in Agriculture and Animal Husbandry

\begin{tabular}{lcccccc}
\hline & & & \multicolumn{3}{c}{ (Per Person/PerYear / Per Hectare) } \\
\hline Category/Activities & \multicolumn{2}{c}{ Agricultural Activities } & \multicolumn{2}{c}{ Animal Husbandry } & \multicolumn{2}{c}{ All Activities } \\
\hline Marginal farmers & Female & Male & Female & Male & Female & Male \\
Small farmers & 91.7 & 193.2 & 288.6 & 119.4 & 380.3 & 312.5 \\
Medium farmers & 38.8 & 133.3 & 108.5 & 44.2 & 147.2 & 177.5 \\
Large farmers & 24.9 & 101.3 & 57.4 & 27.5 & 82.3 & 128.8 \\
\hline Total & 7.7 & 61.0 & 19.6 & 10.3 & 27.4 & 71.3 \\
\hline
\end{tabular}

\section{Economic Value of Family Labour}

The opportunity cost method is used for imputation of economic contribution of women in household income. We have calculated the economic value of family labour by multiplying total persondays put in by family labour by the prevailing wages of male and female labour for different agricultural activities. The female wages were found to be 20 to 25 per cent lower than the male wages for most of the agricultural 
activities.Table 4 presentstotal imputed value of family labour in agricultureand animal husbandry. Total economic value of family labour is estimated at ₹ 53,596 perhousehold from agriculture and animal husbandry. Economic value of female labour in all activities is $₹ 17,978$ and that of male labour is $₹ 35,618$. About 57 per cent of economic contribution of female members comes from animal husbandry and about 43 per cent from agriculture. In case of male members the respective shares are 16 per cent and 84 per cent. Female members contributed about onethird of the total imputed value of work. Their share is about one-fifth in case of agricultural activities and about three-fourths in case of animal husbandry. These figures are a clear evidence of the important economic contribution of women in the household economy.

Table 4: Economic Value of Family Labour in All Activities per Household (₹)

\begin{tabular}{lcccccc}
\hline Activities & \multicolumn{2}{c}{ Economic Value of Family Labour } & \multicolumn{3}{c}{ \% Share of Total Value } \\
& Female & Male & Total & Female & Male & Total \\
\hline Agriculture & 7,749 & 29,868 & 37,617 & 43.10 & 83.86 & 70.19 \\
& $(20.60)$ & $(79.40)$ & $(100.00)$ & & & \\
Animal husbandry & 10,229 & 5,750 & 15,979 & 56.90 & 16.14 & 29.81 \\
& $(64.02)$ & $(35.98)$ & $(100.00)$ & & & \\
Total & 17,978 & 35,618 & 53,596 & 100.00 & 100.00 & 100.00 \\
& $(33.54)$ & $(66.46)$ & $(100.00)$ & & & \\
\hline
\end{tabular}

Note: Figures in brackets show per cent to total value of household work. Economic Value of Family Labour by Size of
Landholding

As shown by Table 5 , the contribution of women in value of family labour declines with the increase in the size of holdings. Thus, females contributed 43.5 per cent of the value of family labour on marginal farms as compared to a share of 34.3 percent on small farms, 32.3 per cent on medium farms and 18.8 percent on large farms.
This is mainly on account of higher participation of femalefamily labour in agriculture on marginal farmsascompared to large farms, which relymore on wage labour. On the other hand, the contribution of male workers increases with rise in size of holdings. In case of animal husbandry work the differences in contribution in value of work on different land size groups are not marked.

Table 5: Economic Value of Family Labour in All Activities by Size of Landholdings (₹)

\begin{tabular}{lcccccccc}
\hline Activity & \multicolumn{2}{c}{ Marginal } & \multicolumn{2}{c}{ Small } & \multicolumn{2}{c}{ Medium } & \multicolumn{2}{c}{ Large } \\
& Females & Males & Females & Males & Females & Males & Females & Males \\
\hline Agriculture & 7,742 & 18,421 & 8,130 & 30,407 & 9,431 & 36,500 & 7,893 & 67,509 \\
& $(29.6)$ & $(70.4)$ & $(21.1)$ & $(78.9)$ & $(20.5)$ & $(79.5)$ & $(10.5)$ & $(89.5)$ \\
Animal husbandry & 11,020 & 5,928 & 10,866 & 5,966 & 10,726 & 5,826 & 9,327 & 6,698 \\
& $(65.0)$ & $(35.0)$ & $(64.6)$ & $(35.4)$ & $(64.8)$ & $(35.2)$ & $(58.2)$ & $(41.8)$ \\
Total & 18,762 & 24,349 & 18,996 & 36,373 & 20,157 & 42,326 & 17,220 & 74,207 \\
& $(43.5)$ & $(56.5)$ & $(34.3)$ & $(58.2)$ & $(32.3)$ & $(67.7)$ & $(18.8)$ & $(81.2)$ \\
\hline
\end{tabular}

Note: Figures in brackets show per cent to total value of household work. 


\section{Contribution of Household Women in Total Household Income}

The share of women in net income from agricultural and non-agricultural sources is worked out on the basis of the ratio of labour hours put in by them. Agricultural income includes net income from cultivation, wage income from agricultural labour and net income from animal husbandry.Non-agricultural income relates to income from services, business, etc. Income from owning or hiring of assets like income from land leasing, sale of water, hiring out of tractor or other sources in which family workers are not directly involved in income generation, was excluded from total household income.
Per household annual income from all sources of sample households comes to ₹ 2,47,271 (Table 6). It varied from ₹ $1,40,108$ in case of marginal farm households to ₹ 4,97,465 in case of large farm households. Agriculture contributed 62.72 per cent of household income, animal husbandry contributed 11.92 per cent and non-agricultural income 25.36 per cent. Share of agriculture in total household income, however,varied from only 35.86 percent in case of marginal farmers to 84.49 per cent in case of large farmers. Marginal and small farmers have to depend on other sources of income to a greater extent because of small size of their holdings.

Table 6: Annual Household Income by Source on Sample Farms by Size Category (₹)

\begin{tabular}{|c|c|c|c|c|c|c|c|c|}
\hline \multirow[t]{2}{*}{$\begin{array}{l}\text { Land Size } \\
\text { Category }\end{array}$} & \multicolumn{2}{|c|}{$\begin{array}{l}\text { Income from } \\
\text { Cultivation }\end{array}$} & \multicolumn{2}{|c|}{$\begin{array}{c}\text { Income from } \\
\text { Animal Husbandry }\end{array}$} & \multicolumn{2}{|c|}{$\begin{array}{l}\text { Total Non- } \\
\text { gricultural Income }\end{array}$} & \multicolumn{2}{|c|}{$\begin{array}{l}\text { Total Household } \\
\text { Income }\end{array}$} \\
\hline & int & $\%$ & Amount & $\%$ & Am & $\%$ & $\mathrm{Am}$ & $\%$ \\
\hline rs & 7 & 35.8 & 29,620 & 21. & & 0 & 08 & 10 \\
\hline & 4 & 54.2 & & 8.27 & & 47 & & 100.00 \\
\hline 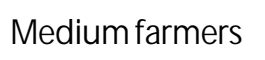 & $1,93,137$ & 65.72 & 29,050 & 0 & 71,686 & נט & 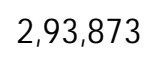 & 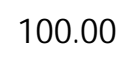 \\
\hline ers & 20,292 & 1 & 34 & 0 & 42 & $56-2 x$ & 4,9 & 100.00 \\
\hline I farmers & $1,55,098$ & 62.72 & 29,464 & 11.92 & 62,709 & 25.36 & $2,47,271$ & 100.00 \\
\hline
\end{tabular}

The contribution of female family members to household income varied from $₹ 39,229$ in case of marginal farmers to ₹ 64,859 for large farmers (Table 7). Women contributed about 20 per cent of total household income. The contribution varied from 28.0 per cent in case of marginal farmer households and 13 per cent in case of large farmer households. Women contributed around 60 per cent of household income from animal husbandry and about $20 \mathrm{per}$ cent of household income from cultivation. But their contribution was nominal in case of nonagricultural income. 
Table 7: Contribution of Household Women in Annual Household Income on Sample Farms by Size Category (₹)

\begin{tabular}{lccccccccc}
\hline $\begin{array}{l}\text { Land Size } \\
\text { Category }\end{array}$ & \multicolumn{2}{c}{$\begin{array}{l}\text { Income from } \\
\text { Cultivation }\end{array}$} & \multicolumn{3}{c}{$\begin{array}{c}\text { Income from } \\
\text { Animal Husbandry }\end{array}$} & $\begin{array}{c}\text { Total Non- } \\
\text { agricultural Income }\end{array}$ & \multicolumn{2}{c}{$\begin{array}{c}\text { Total Household } \\
\text { Income }\end{array}$} \\
\hline Marginal farmers & Amount & $\%$ & Amount & $\%$ & Amount & $\%$ & Amount & $\%$ \\
Small farmers & 14,870 & 29.6 & 19,259 & 65.0 & 5,100 & 8.5 & 39,229 & 28.0 \\
Medium farmers & 39,793 & 21.1 & 17,801 & 64.6 & 600 & 0.9 & 42,194 & 20.3 \\
Large farmers & 44,131 & 10.5 & 18,825 & 64.8 & 1,200 & 1.7 & 59,618 & 20.3 \\
All farmers & 30,709 & 19.8 & 18,053 & 61.3 & 1,875 & 3.0 & 50,637 & 20.5 \\
\hline
\end{tabular}

Agricultural activities contributed about 61 per cent of total income contributed by women, while animal husbandry contributed about 36 per cent (Table 8). But, the share of non-agricultural sources was nominal at 3.7 per cent. The percentage share of agriculture in total female income increased with the size of holding, but it declined with the size of holding in case of income from animal husbandry and non- agricultural sources. In case of marginal farmers income from animal husbandry and nonagricultural activities is relatively larger. The marginal farmers have a smaller land base and therefore,try to maximise their income from other sources. Women also play a relatively more important role in these activities in the case of marginal farmers.

Table 8: Share of Different Sources in Total Household Income Contributed by Women

\begin{tabular}{lcccc}
\hline \multicolumn{1}{c}{ Land Size Category } & $\begin{array}{c}\text { Share of } \\
\text { Agricultural } \\
\text { Income (\%) }\end{array}$ & $\begin{array}{c}\text { Share of } \\
\text { Income from } \\
\text { Animal } \\
\text { Husbandry (\%) }\end{array}$ & $\begin{array}{c}\text { Share of Non- } \\
\text { agricultural } \\
\text { Income (\%) }\end{array}$ & $\begin{array}{c}\text { All Sources } \\
(\%)\end{array}$ \\
\hline Marginal farmers & 37.91 & 49.09 & 13.00 & 100.00 \\
Small farmers & 56.39 & 42.19 & 1.42 & 100.00 \\
Medium farmers & 66.41 & 31.58 & 2.01 & 100.00 \\
Large farmers & 68.04 & 31.03 & 0.93 & 100.00 \\
All farmers & 60.65 & 35.65 & 3.70 & 100.00 \\
\hline
\end{tabular}

\section{Conclusion}

The paper has highlighted the economic contribution of household women in cultivating households on the basis of a field survey of 240 farm householdsin Muzaffarnagar and Bhagpat districts of western UP. On the whole, it is found that household women contribute about 20 per cent of agricultural income and 61 per cent of animal husbandry income. The contribution of female workers in family income is significant in all the farm size households, though the share of women in family income is found to be negatively 
related with the farm size. Ourstudy clearly shows that women household members contribute a significant amount of family labour and income in the farm households. It is, therefore, important that these women are treated as workers and their contribution is dulyaccounted for in national income statistics. Government agencies working in the field of agriculture and rural development should consciously focus on women workers as a special category.They should be given proper training in agriculture and animal husbandry to improve their efficiency and knowledge. Steps need to betaken to ensure access of rural women to agricultural and livestock extension services and other support mechanisms. 


\section{References}

1. Agarwal,Bina (1985), “Work Participation of Rural Women in Third World - Some Data and Conceptual Biases,"Economic and Political Weekly, Review of Agriculture, December 21-28.

2. Goswami, Chandrama (2013), "Female Agricultural Workers in Assam: A Case Study of Darrang District," International Journal of Scientific and Research Publications, Volume 3, Issue 2, February 2013, ISSN 2250-3153.

3. Kaur, Rupinder (2008), "Gender and Social Analysis of Dairy Farming: A Case Study of Punjab," Journal of Rural Development, Vol. 27, No. (1) January-March 2008.

4. Pandey, R.N. (2001), “Women's Contribution to the Economy Through Their Unpaid Household Work",Working Paper No.2, NIPFP, New Delhi.

5. Saradamoni, K (1987), "Labour, Land and Rice Production - Women Involvement in Three States", Economic and Political Weekly, Review of Women Studies, April 25.

6. Sethi, Raj Mohini (1982), "Female Labour in Agriculture:A Case of Punjab,"Department of Sociology, Punjab University, Chandigarh.

7. (1991), “Women in Agriculture: A Study of Himachal Pradesh," Rawat Publications, Jaipur.

8. Tuteja, Usha (2000), "Contribution of Female Agricultural Workers in Family Income and their Status in Haryana," Indian Journal of Agriculture Economics, Vol.55, No.2, pp.32-67.

9. Unni, J eemol (1992), "Women's Participation in Indian Agriculture," Oxford and IBH Publishing Co. Pvt. Ltd., New Delhi.

10. Varma, ShashiKanta (1992),“Women in Agriculture- A Socio-Economic Analysis,"Concept Publishing Company, New Delhi.

11. Vishwanathan, Maithili (1994), "Women in Agriculture and Rural Development," Printwell, Jaipur.

12. Wasnik, K.P. (2006), "Women in Agriculture-Strategy for Socio-Economic Empowerment," Kalpag Publications, New Delhi. 